\title{
Varietal Susceptibility of Improved Cowpea Vigna unguiculata (L.) (Walp.) Cultivars to Field and Storage Pests
}

\author{
P. K. Baidoo ${ }^{1} \&$ M. B. Mochiah ${ }^{2}$ \\ ${ }^{1}$ Department of Theoretical and Applied Biology, Kwame Nkrumah University of Science and Technology, \\ Kumasi, Ghana \\ ${ }^{2}$ Entomology Section, Crops Research Institute, P.O. Box 3785, Kwadaso, Kumasi, Ghana \\ Correspondence: P. K. Baidoo, Department of Theoretical and Applied Biology, Kwame Nkrumah University of \\ Science and Technology, Kumasi, Ghana. E-mail: pkbaidoo2002@yahoo.com
}

Received: November 7, 2013 Accepted: February 12, 2014 Online Published: March 26, 2014

doi:10.5539/sar.v3n2p69

URL: http://dx.doi.org/10.5539/sar.v3n2p69

\begin{abstract}
Cowpea, Vigna unguiculata is widely cultivated in the tropics and subtropics as food for man and livestock. The crop is highly prone to pests and diseases which limit its production. Resistant cowpea varieties have become increasingly important in the management of both field and storage pests. Three improved cowpea varieties and one local variety were screened for their susceptibility to field and storage pests. The experiment was conducted in a randomized complete block design with four treatments and three replications. The different pests infesting the plants were identified and counted. Aphids and thrips were scored on a scale of 0-5, depending on the levels of infestations. Natural enemies' numbers, leaf damage, pod damage and yield were assessed. Callosobruchus maculatus infestations during storage and weight reduction were determined over a six week period. Aphids and M. sjostedti score, M. virtrata and Empoasca sp. numbers did not differ significantly; however, significantly more pod sucking bubs attacked the local variety than the improved varieties. Natural enemies' numbers on the various cultivars did not differ significantly. Yield was however significantly better in the improved varieties. The local variety suffered the largest weight reduction (20.91\%) during storage while Nhyira suffered the least weight reduction of $4.23 \%$. The use of improved varieties and application of pests' control measures will increase cowpea production in Ghana.
\end{abstract}

Keywords: aphids, Callosobruchus maculatus, damaged leaves, infestation, susceptibility

\section{Introduction}

Cowpea, Vigna unguiculata, (L.) (Walp.) is one of the most important legume crops cultivated by many resource-poor farmers in many countries of tropical Africa, Asia and South America (Kabululu, 2008). It is either grown in a monocrop or often intercropped with various crops such as millet, sorghum and maize in many African countries; especially in the drier regions of the continent (Singh \& Sharma, 1996). It is a rich source of protein and certain minerals necessary for the healthy growth of humans and animals such as cattle (Uzogara \& Ofunya, 1992). According to Bressani (1985), on the average cowpea contains $23-25 \%$ protein, 50-67\% carbohydrate and $1.9 \%$ fat, making it one of the most nutritious crops. Apart from its importance in the diets of many people in developing countries it is an important source of hay for cattle in many parts of the world (Timko et al., 2007). The crop has considerable adaptation to high temperatures and drought compared to other crops (Hall et al., 2002; Hall, 2004) and is widely adapted to different climatic conditions in Africa. Apart from its importance as a source of food for man and cattle, the crop also contributes to improving and maintaining the fertility of the soil wherever it is cultivated. Cowpea roots harbour Rhizobium sp that is able to fix nitrate, even in very poor soils (Blade et al., 1997).

In West Africa, where small-scale production of cowpea is practised, the crop is grown in combination with other crops such as millet and sorghum. The application of fertilizers to improve yield is generally not practiced, either because they are too expensive or may not be available to the peasant farmer. The crop is also highly susceptible to pests which attack and cause considerable damage, thereby limiting its production (Koona et al., 2002; Dugie et al., 2009), leading to low yields and economic losses to the farmer. The low yield is also attributed to other factors such as water shortage and low soil fertility (Adam, 1990). Cowpea is attacked by a number of pests, both on the field and in storage. If these pests are not controlled they can cause up to $100 \%$ loss of crop yield 
(Ezueh, 1981; Singh et al., 1990). Cowpea pests affect the plant at different stages of its development. From emergence, through maturity to harvest and during storage, different pests affect the plant leading to significant losses to the farmer.

In Ghana, the important field pests of cowpea include the aphid, Aphis craccivora (Hemiptera: Aphididae), the flower bud thrip Megalurothrip sjostedti Trybom (Thysanoptera: Thripidae), the pod borer, Maruca vitrata Fab. (Lepidoptera: Pyralidae) and pod sucking bugs (PSB) which include Clavigralla sp Stal. (Hemiptera: Coreidae) and Raptortis dentipes Fab. (Hemiptera: Alydidae) (Tanzubil, 1991). These cause significant reduction in cowpea yield. In addition cowpea seeds in storage are significantly affected by the storage pest Callosobruchus maculatus (Adam \& Baidoo, 2008). This pest can damage about $50 \%$ of the seeds after only about four months in storage (Caswell, 1984).

The management of cowpea pests is very crucial to sustainable production of the crop. The readily available method of controlling cowpea pests is the application of chemical insecticides. Several chemical insecticides have been formulated for the management of insect pests; these are often too expensive to the resource-poor farmer and not readily available (Wolfson et al., 1991). The most important negative effects of the use of chemical insecticides are contamination of food and water sources. One alternative to the use of insecticides is planting of resistant cultivars which will limit the use of these insecticides (Tanzubil et al., 2008).

The development and use of resistant cultivars offers a simple, cheap and attractive approach to the reduction of damage caused by pests (Jackai \& Asante, 2001). In Ghana, the Crop Research Institute (CRI) of the Council for Scientific and Industrial Research (CSIR) has developed improved cowpea cultivars (Bennet-Lartey \& Ofori, 2000) which are believed to be more resilient to insect pests' attack compared to the local varieties. The study therefore assessed the potential of three improved cowpea cultivars in the management of field and storage pests of cowpea and how the level of field pests' infestation affected yield.

\section{Materials and Methods}

\subsection{Study location}

The study was carried out on an experimental farm near the Department of Theoretical and Applied Biology of Kwame Nkrumah University of Science and Technology, Kumasi, Ghana. The study area is located within the forest zone of Ghana and is characterized by an annual rainfall of about $730 \mathrm{~mm}$ and annual minimum and maximum temperatures of about $21.5^{\circ} \mathrm{C}$ and $32.1^{\circ} \mathrm{C}$ respectively (Addo-Fordjour et al., 2007). The site has soil type intermediate between sand and clay with the top soil about $30 \mathrm{~cm}$ deep. Humidity during the study period ranged between $76 \%$ and $85 \%$.

\subsection{Land Preparation and Planting}

The land was cleared and root stumps removed before sowing the seeds. Twelve beds each measuring $5.0 \mathrm{~m} \times$ $2.5 \mathrm{~m}$ were raised, with an alley of $0.5 \mathrm{~m}$ between them. Three improved cowpea varieties namely Asontem, Nhyira and Asetenapa were obtained from the Crops Research Institute (CRI) of the Council for Scientific and Industrial Research (CSIR), Kwadaso Kumasi and a local variety which served as the control were used as treatments. The experiment was conducted in a randomized complete block design (RCBD) with three replications. Cowpea seeds were sown at 3 seeds per hole. Planting space was $50 \mathrm{~cm}$ between rows and $50 \mathrm{~cm}$ between the columns; there were 8 rows and 5 columns; thus there were 40 plant stands per plot. Thinning out of the seedlings was done to 1 seedling per stand two weeks after germination. No fertilizer and insecticides were applied during the growth of the plants. Weed management on the plots was first done two weeks after germination and subsequently every two weeks.

\subsection{Data Collection}

Data were collected on the various insect pests that attacked the crop. Scouting for signs of pest infestation started two weeks after germination. Assessment of aphids was done weekly. A visual rating scale of $0-5$ based on colony size of the aphids by Salifu (1982) was used; (no aphid $=0$; few individuals $=1$; few isolated small colonies $=2$; several small colonies $=3$; large isolated colonies $=4$; large continuous colonies $=5$ ). This was done on each plot for 10 randomly selected plants.

Leafhoppers and aphids were assessed from two weeks after germination (WAG) to $10 \mathrm{WAG}$, flower thrips damage were assessed from $3 \mathrm{WAG}$, Maruca virtrata numbers and damage assessment was done at the pod formation stage ( $8 \mathrm{WAG}$ ); natural enemies of cowpea pest were also identified and counted alongside the pests.

\subsubsection{Damaged Leaves}

This was done by examining and recording the numbers of leaves damaged in the inner row of plants. Leaves 
with holes on them and distorted in shape were considered as damaged. These were counted and recorded weekly from week 3-10 and the means computed for each treatment.

\subsubsection{Flower Thrips Damage}

Plants in the inner rows were examined for thrips from 3 WAG to 7 WAG. Scoring was done based on visual examination of flowers, flower buds and terminal bud damage using the scoring chart shown in Table 1 below:

Table 1. Flower thrips scoring chart

\begin{tabular}{ll}
\hline Symptom & Score \\
\hline No browning/drying of stipules, leaf or flower bud; no bud abscission & 1 \\
Initiation of browning of stipules, leaf or flower bud; no bud abscission & 2 \\
Distinct browning/drying of stipules and leaf or flower bud; some bud abscission & 3 \\
Serious bud abscission accompanied by browning/drying of stipules and buds & 4 \\
Very severe browning/drying of stipules and buds; & 5 \\
distinct non-elongation of most or all of the peduncles & \\
\hline
\end{tabular}

\subsubsection{Pod Damage}

Assessment of pod damage by M. virtrata was done weekly from 8 WAG to 12 WAG. The pods were examined carefully and those that showed two or more holes were considered damaged. Percent damaged pods were calculated using the formula:

Percent damage $=\frac{\text { Total number of damaged pods }}{\text { Total number of pods }} \times 100 \%$

\subsubsection{Harvesting and Storage}

Dried pods were harvested from the inner rows and put into labelled envelopes. They were sun-dried for 3 days after which the seeds were removed, weighed and stored in transparent bottles, the mouth of which were covered with nylon mesh and secured with a rubber band. Eight days after storage, the seeds were sieved and adult $C$. maculatus recovered from each treatment were counted, thrown away and the seeds placed back in their respective containers. This was done consecutively for six weeks. At the end of the storage period the seeds were weighed and the weight difference was calculated.

\subsection{Data Analysis}

Data collected were subjected to the GLM procedure (SAS Institute, 2011). Analysis of variance was done on the different parameters that were studied. When significant differences were obtained $(\mathrm{P}<0.05)$ means were separated with Student- Neuman Keul's Test (SNK).

\section{Results}

\subsection{Pests of Cowpea}

The different pests that attacked the crop on the field were: Aphis craccivora, Megalurothrip sjostedti, Maruca virtrata, pod sucking bug, Riptortis dentipes and Empoasca sp. These pests attacked the crop at different stages of growth of the plant. Aphis craccivora infestation was detected at $2 \mathrm{WAG}$ on all the plots; however, by the end of the $5^{\text {th }}$ week their numbers had reduced drastically. They were found only on the local variety in week 7 , having completely disappeared from all the improved varieties (Figure 1). A. craccivora score was largest on the local variety and least on Nhyira (Table 2), however, the differences in A. craccivora score on the various varieties were not significantly different $(\mathrm{P}=0.85)$. M. sjostedti was identified on the plants at 3 WAG, with mean score ranging from 0.60 on Asetenapa to 3.53 on the control plants. The differences were however not significant $(\mathrm{P}=0.42)$. Similarly, the numbers of Empoasca sp. on the various varieties were not significantly different. Pod sucking bug, Riptortus dentipes numbers ranged from 2.60 on Asetsnapa to 5.53 on the control plots. Significantly more of them attacked the local variety than Asetenapa and Asontem, but the numbers of $R$. dentipes on the local variety and Nhyira did not differ significantly (Table 2). 


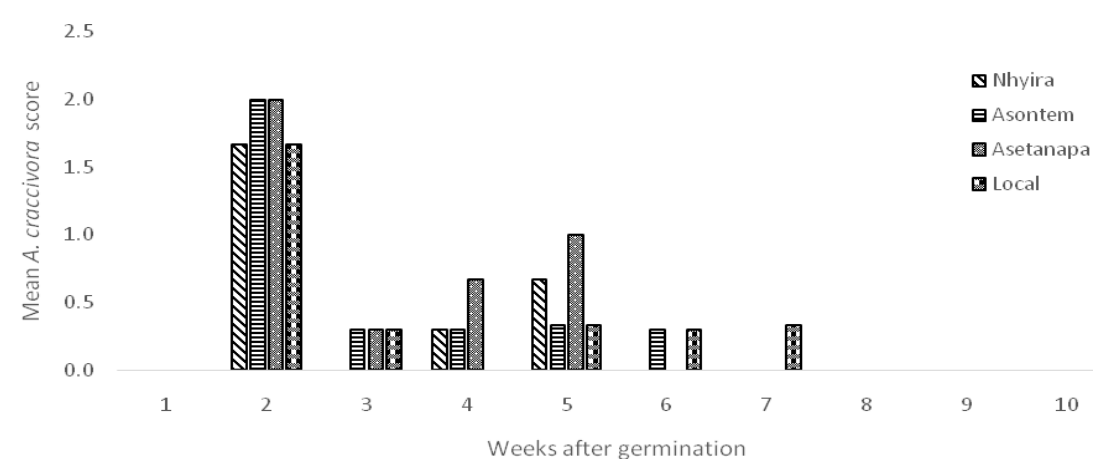

Figure 1. Mean Aphis craccivora score on different varieties of cowpea

Table 2. Different species of pests encountered on cowpea plants

\begin{tabular}{llllll}
\hline Cowpea variety & $\begin{array}{l}\text { Aphis } \\
\text { craccivora }\end{array}$ & $\begin{array}{l}\text { Megalurothrips } \\
\text { sjostedti }\end{array}$ & $\begin{array}{l}\text { Riptortis } \\
\text { dentipes }\end{array}$ & Empoasca \% & $\begin{array}{l}\text { Maruca virtrata } \\
\text { damage }\end{array}$ \\
\hline Asetenapa & $0.48^{\mathrm{a}} \pm 0.16$ & $0.60^{\mathrm{a}} \pm 0.19$ & $2.60^{\mathrm{a}} \pm 0.72$ & $1.00^{\mathrm{a}} \pm 0.28$ & $47.25^{\mathrm{a}} \pm 0.35$ \\
Asontem & $0.48^{\mathrm{a}} \pm 0.18$ & $1.07^{\mathrm{a}} \pm 0.33$ & $2.60^{\mathrm{a}} \pm 0.59$ & $1.10^{\mathrm{a}} \pm 0.25$ & $46.50^{\mathrm{a}} \pm 3.90$ \\
Nhyira & $0.33^{\mathrm{a}} \pm 0.14$ & $0.67^{\mathrm{a}} \pm 0.23$ & $4.07^{\mathrm{b}} \pm 0.71$ & $1.10^{\mathrm{a}} \pm 0.28$ & $49.00^{\mathrm{a}} \pm 1.50$ \\
Control & $0.52^{\mathrm{a}} \pm 0.14$ & $3.53^{\mathrm{a}} \pm 2.82$ & $5.53^{\mathrm{b}} \pm 0.78$ & $1.43^{\mathrm{a}} \pm 0.36$ & $98.50^{\mathrm{b}} \pm 140$ \\
F -value & 0.855 & 0.950 & 4.025 & 0.400 & 54.050 \\
P & 0.27 & 0.42 & 0.01 & 0.75 & 0.01
\end{tabular}

Within columns means with the same letter are not significantly different $(\mathrm{P}>0.05)$

\subsection{Natural Enemies of Aphis craccivora}

Ladybird beetles, Coccinella sp and black ants, Camponotus pensylvanicus were the natural enemies of Aphis craccivora. Coccinella sp numbers were generally low, ranging from a mean of 0.24 on the local variety to 0.67 on Asetenapa; no significant difference in numbers of Coccinella sp were observed $(P=0.220)$. Similarly no significant differences were observed in C. pensylvanicus numbers on the various cowpea varieties (Table 3).

Table 3. Mean numbers of natural enemies of Aphis craccivora

\begin{tabular}{lll}
\hline Variety & Coccinella sp & C. pensylvanicus \\
\hline Asetenapa & $0.67^{\mathrm{a}} \pm 0.19$ & $6.57^{\mathrm{a}} \pm 1.11$ \\
Asontem & $0.33^{\mathrm{a}} \pm 0.13$ & $5.76^{\mathrm{a}} \pm 0.90$ \\
Nhyira & $0.48^{\mathrm{a}} \pm 0.13$ & $8.10^{\mathrm{a}} \pm 1.26$ \\
Local & $0.24^{\mathrm{a}} \pm 0.15$ & $6.19^{\mathrm{a}} \pm 1.16$ \\
F value & 1.52 & 0.83 \\
$\mathrm{P}$ & 0.220 & 0.485 \\
\hline
\end{tabular}

Within columns means with the same letter are not significantly different $(\mathrm{P}>0.05)$.

\subsection{Damaged Plants and Yield Of Cowpea}

Leaf damage assessment revealed a larger number on the local variety than on the improved varieties, even though the differences were not significant $(\mathrm{P}=0.43)$. Asetenapa recorded the least number of damaged pods (2.06) while the local variety recorded the largest number of damaged pods (11.80); however, the differences were not significant (Table 4). The numbers of pods harvested from the various cowpea varieties did not differ significantly $(\mathrm{P}=0.125)$. With regard to the performance of the plants in terms of yield, Nhyira performed best 
while the local variety recorded the poorest yield. The improved varieties performed significantly better than the local variety $(\mathrm{P}=0.004)$.

Table 4. Effects of cowpea variety on pest damage and yield

\begin{tabular}{lllll}
\hline Variety & Leaf damage & Number of pods & Pod damage & Yield(g) \\
\hline Asetenapa & $9.86^{\mathrm{a}} \pm 1.06$ & $17.00^{\mathrm{a}} \pm 5.92$ & $2.06^{\mathrm{a}} \pm 1.18$ & $52.14^{\mathrm{a}} \pm 5.26$ \\
Asontem & $8.20^{\mathrm{a}} \pm 1.13$ & $14.01^{\mathrm{a}} \pm 6.22$ & $3.25^{\mathrm{a}} \pm 2.42$ & $49.45^{\mathrm{a}} \pm 9.35$ \\
Nhyira & $7.75^{\mathrm{a}} \pm 0.90$ & $6.93^{\mathrm{a}} \pm 10.08$ & $3.93^{\mathrm{a}} \pm 1.71$ & $70.91^{\mathrm{a}} \pm 3.11$ \\
Local & $9.88^{\mathrm{a}} \pm 1.38$ & $33.11^{\mathrm{a}} \pm 9.29$ & $11.80^{\mathrm{a}} \pm 8.50$ & $10.95^{\mathrm{b}} \pm 3.11$ \\
F- value & 0.94 & 1.98 & 0.87 & 27.47 \\
$\mathrm{P}$ & 0.43 & 0.125 & 0.460 & 0.004 \\
\hline
\end{tabular}

Within columns means with the same letter are not significantly different $(\mathrm{P}>0.05)$.

\subsection{Storage Pest}

At the end of the storage period, it was observed that Asetenapa was infested most with C. maculatus, while the local variety recorded the least infestation. Adult $C$. maculatus numbers increased from week 1 to week 6 . As a result of $C$. maculatus infestation there were reductions in seed weight at the end of the storage period, ranging from $4.23 \%$ in Nhyira to $20.91 \%$ in the local variety.

\section{Discussion}

In this study it was observed that all four varieties were susceptible to cowpea pests to some extent. This was an indication that none of the varieties used was resistant to any of the pests. The plants were infested with $A$. craccivora two weeks after germination. The activities of this pest rob the plant of essential food nutrients (Baidoo et al., 2012) and can also transmit viral diseases as a result of their feeding activities (Chalfant, 1976). Aphis craccivora feeds on the stem, terminal shoot and petioles of the seedling causing stunted growth and death of affected plants (Chalfant et al., 1985). Due to the high rate of reproduction, their numbers increased rapidly. Large colonies were formed with individuals feeding on the under surface of the leaves and young shoots, causing stunted growth and distorted leaves, discolouration and premature leaf fall.

The sudden reduction in A. craccivora numbers six weeks after germination could be due to the presence of their natural enemies, Coccinella sp. and black ants, Camponotus pensylvanicus, which were also present on cowpea during the period of infestation. The local variety which recorded the largest score of $A$. craccivora recorded the least number of Coccinella sp. Meanwhile Asetanapa, which recorded the largest Coccinella sp. recorded the second largest A. craccivora score, an indication that this natural enemy was not effective in controlling aphid numbers on cowpea.

As a result of high infestation on the local variety, leaf damage was greatest, an indication of high susceptibility to A. craccivora. During the pre-flowering period, $M$. sjostedti nymphs and adults were observed feeding on bracts and stipules. Feeding on the stipules resulted in deformation with brownish yellowish spots. Subsequently, they attacked the flower buds and the flowers. These effects of $M$. sjostedti infestation have been reported by other authors (Ezueh, 1981; Agyen-Sampong, 1978). The results of the study indicated that damage by M. sjostedti did not differ significantly among the cowpea varieties; however, the effects of this pest were most severe in the local variety. Damage caused by this pest impacted negatively on pod formation and the number of pods formed. Linking flower thrips damage to pod numbers, it was observed that the local variety which recorded the largest damage surprisingly recorded the largest number of pods, an indication that infestation of cowpea plants with $M$. sjostedti did not significantly affect pod formation in that variety. This could be attributed to the phenomenon of tolerance which is based on the assumption that infestation and damage are not synonymous (Singh \& Jackai, 1985). Thus the local variety which recorded the largest infestation produced more pods than Asetenapa and Asontem. Even though the local variety produced more pods than some of the improved varieties, seed formation was very poor. This resulted in significantly lower yield compared to all the improved varieties.

The significantly low yield in the local variety could be attributed to severe damage by the pod borer Maruca virtrata. This pest caused significantly greater damage to the local variety than the improved varieties. It is one 
of the major pests of cowpea causing severe damage to the pods. Infestation by M. virtrata coincided with flowering and pod formation. The young larvae fed on the terminal shoots and peduncles during the vegetative growth, while the matured larvae fed on the newly formed pods. Similar observations have been reported by Okeyo-Owuor et al. (1983).

In Ghana and many parts of Africa, the main storage pests of cowpea are the various species of the genus Callosobruchus, the most important ones being C. maculatus and C. chinensis (Singh \& Jackai, 1985). Infestation of cowpea by Callosobruchus sp. begins in the field and carried into storage. During the period of storage, Asetenapa recorded the largest number of $C$. maculatus, while the local variety recorded the least. The low number of $C$. maculatus on the local variety does not mean resistance to the pest. In this variety, yield was very poor and therefore there were fewer seeds for the adult insect to lay their eggs on. In addition, the weight and volume of the seeds are two other factors responsible for oviposition preference (Patil \& Jadhav, 1985). This explains why the local variety which produced fewer seeds recorded very low numbers of C. maculatus. Even though fewer $C$. maculatus adults were obtained from the local variety, it recorded the largest weight reduction of $20.91 \%$ in just 42 days of storage compared to $4.23 \%$ in Nhyira. Keita et al. (2000) also reported that $C$. maculatus can cause weight loss up to $60 \%$ when cowpea seeds are stored without any protection. Golob (1993) observed that in Northern Ghana, levels of cowpea damage varied from 15 to $94 \%$. Golob et al. (1996), however, concluded that even though C. maculatus attacked cowpea, weight loss rarely exceeds $9 \%$ even after six months of storage. Cowpea seeds contain features such as coat texture and hardness of seed coat which determine their suitability for oviposition (Obeng-Ofori \& Darkwah, 2002). It has been reported that cowpea bruchids prefer smooth and soft seed surfaces as they facilitate oviposition (Adam \& Baidoo, 2008). The improved varieties which were used for the study have smooth seed coats and thus were equally susceptible to C. maculatus, indicating that seed coat texture does not necessarily confer resistance to the pest.

\section{Conclusion}

None of the cowpea varieties used in the study was resistant to both the field and storage pests. However, the improved varieties suffered less damage than the local variety, indicating certain level of tolerance. Natural enemies of cowpea pests encountered on the field could not significantly reduce pest numbers. In the present study, no pest control measures were adopted but if our quest to improve and increase cowpea production is to be achieved then planting of improved varieties as well as some pest management measures must be applied both on the field and during storage.

\section{References}

Adam, J. I., \& Baidoo, P. K. (2008). Susceptibility of five cowpea (Vigna unguiculata) varieties to attack by Callosobruchus maculatus (Fab.) [Coleoptera:Bruchidae]. Journal of the Ghana Science Association, 10(2), 85-92.

Adam, T. (1990). Diseases affecting cowpea (Vigna unguiculata) (L.) Walp. in Niger, Ambio. pp. 358-360.

Addo-Fordjour, P., Yeboah-Gyan, K., Lawson, B. W. L., \& Akanwariwiak, W. G. (2007). Diversity and distribution of ferns on the campus of Kwame Nkrumah University of Science and Technology, Kumasi. Journal of Science and Technology, 27(1), 35-44.

Agyen-Sampong, M. (1978). Effects Pests of cowpea and their control in Ghana. pp. 85-92.

Baidoo, P. K., Baidoe-Ansah, D., \& Agbonu, I. (2012). Effects of neem (Azadirachta indica A. Juss) products on Aphis craccivora and its predator, Harmonia axyridis on cowpea. American Journal of Experimental Agriculture, 2(2), 198-206.

Bennet-Lartey, S. O., \& Ofori, K. (2000). Variability in some quantitative characters of cowpea (Vigna unguiculata (L.) Walp.) landraces in Ghana. Ghana Journal of Agricultural Science, 33(2), 165-170. http://dx.doi.org/10.4314/gjas.v33i2.1866

Blade, S. F., Shetty, S. V. R., Terao, T., \& Singh, B. B. (1997). Recent developments in cowpea cropping systems research. In B. B. Singh \& M. Raj (Eds.), Advances in Cowpea Research. Experimental Agriculture, 34, 475-486.

Bressani, R. (1985). Nutritive value of cowpea: In cowpea Research, Production and Utilization. In S. R. Singh \& K. O. Rachie (Eds.) (pp. 353-359). John Wiley and Sons Ltd.

Caswell, G. H. (1984). The value of the pod in protecting cowpea seed from attack by bruchid beetles. Samaru Journal of Agricultural Research, 2, 49-55.

Chalfant, R. B., Leigh, T. F., Renwick, J. A., Messina, F. J. \& Schalk, J. M. (1985). Entomological Research on 
cowpea pest in the USA. In S. R. Singh \& K. O. Rachie (Eds.), Cowpea Research, Production and Utilization (pp. 267-373). London: John Wiley, and Sons Ltd.

Chalfant, R. B. (1976). Chemical control of insect pests of the southern pea in Georgia. Georgia Agricultural Experimental Station Research Bulletin, 179, 31.

Dugie, I. Y., Omoigui, L. O., Ekeleme, F., Kamara, A. Y., \& Ajeigbe, H. (2009). Farmers Guide to cowpea production in West Africa. IITA, Ibadan, Nigeria. p. 20.

Ezueh, M. I. (1981). The biological basis of resistance in cowpea to the cowpea moth, Cydia ptychora (Lepidoptera; Olethreutidae). Annals of Applied Biology, 99, 313-321. http://dx.doi.org/10.1111/j.1744-7348.1981.tb04801.x

Golob, P. (1993). Phosphine: A fumigant for small-scale application in Northern Ghana. NRI, 4:5.

Golob, P., Strinfellow, R., \& Asante, E. O. (1996). A review of the storage and marketing systems of the major food grains in Northern Ghana, NRI, 11: 64.

Hall, A. E. (2004). Breeding for adaptation to drought and heat in cowpea. European Journal of Agronomy, 21, 447-454. http://dx.doi.org/10.1016/j.eja.2004.07.005

Hall, E., Cisse, N., Thiaw, S., Elawad, H. O. A., Ehlers, J. D., Ismail, A., ... McWaters, K. H. (2002). Development of cowpea cultivars and germplasm by the bean/cowpea CRSP. Field Crop Research, 82, 103-134. http://dx.doi.org/10.1016/S0378-4290(03)00033-9

Jackai, L. E. N., \& Asante, S. K. (2001). A case for the standardisation of protocols used in screening cowpea, Vigna unguiculata for resistance to Callosobruchus maculatus (Fab.) (Coleoptera: Bruchidae). Journal of Stored Products Research, 39, 251-263. http://dx.doi.org/10.1016/S0022-474X(01)00058-3

Kabululu, M. S. (2008). Cowpea, (Vigna unguiculata) variety mixtures for stable and optimal leaf and seed yield when intercropped with maize in Central Tanzania. MSc. Thesis, Georg-August-Unuversitat, Gottingen, Germany. p. 75.

Keita, S. M., Vincent, C., Schmit., J. B., Ramaswamy, S., \& Belanger, A. (2000). Effects of various essential oils on Callosobruchus maculatus (F.) (Coleoptera; Bruchidae). Journal of Stored Products Research, 36, 355-364. http://dx.doi.org/10.1016/S0022-474X(99)00055-7

Koona, P., Osisanya, E. O., Jackai, L. E. N., Tamo, M., \& Markham, R. H. (2002). Resistance in accessions of cowpea to the Coreid pod bug Clavigralla tomentosicollis (Hemiptera: Coreidae). Journal of Economic Entomology, 95, 1281-1288. http://dx.doi.org/10.1603/0022-0493-95.6.1281

Obeng-Ofori, D., \& Dankwah, J. A. (2002). Biological effect of four protectants applied to stored bambara groundnuts against infestation by Callosobruchus maculatus (Fab.) (Coleoptera: Bruchidae). Journal of the Ghana Science Association, 4(2), 41-51.

Okeyo-Owuor, J. B., Agwardo, P. O., \& Simbi, C. O. J. (1983). Studies on the legume pod borer, Maruca testulalis (Geyer) larval population. Insect Science and its Application, 4, 75-81.

Patil, S. M., \& Jadhav, L. D. (1985). Studies on the relative susceptibility of some promising varieties of pea, Pisum sativum to pulse beetle Callosobruchus maculatus in storage. Bulletin of Grain Technology, 20, 48.

SAS Institute. (2011). Statistical Analysis Systems, SAS/STAT. User's guide version 9(1) Cary, NC: SAS Institute Inc.

Salifu, A. B. (1982). Biology of cowpea flower thrips and host plant resistance. MSc. Thesis, University of Ghana.

Singh, S. R., \& Jackai, L. E. N. (1985). Insects of cowpea in Africa: Their life cycles, economic importance and potential for control. In S. R. Singh \& K. O. Rachie, (Eds.). Cowpea Research Production and Utilization (pp. 217-231). London: John Wiley and Sons, Chichester.

Singh, S. R., Jackai, L. E. N., Dos Santos, J. H. R., \& Adalla, C. B. (1990). Insect pests of cowpea. In S. R. Singh (Ed.) Insect Pests of tropical Food Legumes (pp. 43-89). London: John Wiley and Sons Chichester.

Singh, B. B., \& Sharma, B. (1996). Restructuring cowpea for higher yield. Indian Journal of Genetics, 56, 389-405.

Tanzubil, T. B., Zakariah, M., \& Alem, A. (2008). Integrating host plant resistance and chemical control in management of cowpea pests. Australian Journal of Crop Science, 2(3), 115-120. 
Tanzubil, P. B. (1991). Control of some insect pests of cowpea (Vigna unguiculata) with neem (Azadirachta indica A. Juss) in Northern Ghana. International Journal of Pest Management, 37(3), 216-217.

Timko, M. P., Ehlers, J. D., \& Roberts, P. A. (2007). Cowpea. In C. Kole (Ed.) Genome mapping and molecular breeding in plants, pulses, sugar and tuber crops. 3. pp. 49-65.

Uzogara, S. G., \& Ofunya, Z. M. (1992). Processing and utilization of cowpea in developing countries: A review. Journal of Food Processing and Preservation, 16(2), 105-147.

Wolfson, J. L., Shade, Mentzer, P. E., \& Murdock, L. L. (1991). Efficacy of ash for controlling infestations of Callosobruchus maculatus (F.) (Coleoptera: Bruchidae) in stored cowpeas. Journal of Stored Products Research., 27, 239-243.

\section{Copyrights}

Copyright for this article is retained by the author(s), with first publication rights granted to the journal.

This is an open-access article distributed under the terms and conditions of the Creative Commons Attribution license (http://creativecommons.org/licenses/by/3.0/). 